\title{
APPLICATION OF THE TAGUCHI METHOD TO SELECT THE OPTIMUM CUTTING PARAMETERS FOR TANGENTIAL CYLINDRICAL GRINDING OF AISI D3 TOOL STEEL
}

\author{
UPORABA TAGUCHI METODE ZA IZBIRO OPTIMALNIH \\ PARAMETROV ODREZAVANJA PRI TANGENCIALNEM \\ CILINDRIČNEM BRUŠENJU ORODNEGA JEKLA AISI D3
}

\author{
Cetin Ozay ${ }^{1}$, Hasan Ballikaya ${ }^{2}$, Vedat Savas ${ }^{1}$ \\ ${ }^{1}$ Department of Mechanical Engineering, Faculty of Technology, University of Firat, 23119 Elazig, Turkey \\ ${ }^{2}$ Ortakoy Vocational High School, University of Aksaray, Aksaray, Turkey \\ cozay@firat.edu.tr, hballikaya@aksaray.edu.tr, vsavas@firat.edu.tr \\ Prejem rokopisa - received: 2014-12-06; sprejem za objavo - accepted for publication: 2015-02-10
}

doi: $10.17222 / \mathrm{mit} .2014 .293$

The purpose of this research was an analysis of the optimum cutting conditions for the lowest surface roughness in tangential cylindrical grinding of the AISI D3 tool steel using the Taguchi method. In this experimental investigation, the surface roughness with various wheel speeds, workpiece speeds, feed rates and depths was observed. The surface roughness was investigated employing the Taguchi design of experiments and an analysis of variance (ANOVA). Significant machining parameters were identified using the signal-to-noise ratio. The results of the experiments indicate that the wheel speed and feed rate have dominating effects on the surface roughness during the cutting. The developed new grinding process can be used in the machining industries in order to determine the optimum cutting parameters for the minimum surface roughness.

Keywords: tangential cylindrical grinding, Taguchi method, surface roughness, ANOVA

Članek predstavlja analizo optimalnih pogojev rezanja s Taguchi metodo, za doseganje najmanjše hrapavosti pri tangencialnem cilindričnem brušenju orodnega jekla AISI D3. Pri teh eksperimentih je bila opazovana hrapavost površine pri različnih hitrostih kolesa, različnih hitrostih obdelovanca ter različnih hitrostih in globinah podajanja. Površinska hrapavost je bila preiskovana $\mathrm{z}$ uporabo Taguchi-jeve postavitve preizkusov in analize variance (ANOVA). Pomembni parametri obdelave so bili identificirani $z$ uporabo razmerja signal - hrup. Rezultati eksperimentov kažejo, da imata hitrost kolesa in hitrost podajanja prevladujočo vlogo pri hrapavosti površine in parametrih rezanja. Razvoj novega postopka brušenja se lahko uporabi v strojni industriji za določanje optimalnih pogojev rezanja pri minimalni hrapavosti površine.

Ključne besede: tangencialno cilindrično brušenje, Taguchi metoda, hrapavost površine, ANOVA

\section{INTRODUCTION}

Recently, increased production quality, a reduction in the process time, an improvement in dimensional accuracy and improved workplace-safety conditions have been studied with respect to the development of production methods. The Taguchi method and ANOVA analysis used for determining the optimum values reduce the number of experimental studies while providing more accurate results.

\subsection{Grinding}

Grinding is a finishing process used to improve the surface finish and the abrasive materials and tighten the tolerance on flat and cylindrical surfaces by removing a small amount of the material. Grinding is an essential process for the final machining of the components requiring smooth surfaces and precise tolerances.

Grinding methods vary depending on the cutting tool and the shape, the location and the movement of the workpiece. The cylindrical grinding method is one of these methods. The cylindrical grinding method is a final machining method, often used for processing interior and exterior surfaces of cylindrical workpieces. This method increases the surface quality of the workpieces and provides the required measurement and tolerance. Moreover, grinding is a method, which has a significant effect on the corrosion rate, the fracture strength, the abrasion and the magnetic features of a workpiece.

Large-diameter grinding wheels are used as the cutting tools for the cylindrical grinding method. They are composed of a grinding wheel, abrasive particles and sealants that join them together. Some problems occur while fixing these cutting tools to the bench and during their operation because of the errors that occurred during the manufacturing of these tools and because they are of large dimensions. The wheel is not balanced since hard particles were not homogeneously dispersed during the manufacturing of the wheel. An unbalanced wheel increases the centrifugal force while turning and cannot reach high speeds; the vibration increases, the surface quality deteriorates and the explosion risk of the wheel increases since the contact of the wheel with the workpiece is imbalanced. Such problems affect the manufacturing and manufacturer adversely. 
The grinding process has an important place in highly delicate procedures performed during the manufacturing of the molds used in the molding sector. Some studies of the cylindrical grinding method have been conducted recently.

Cylindrical grinding is used to grind the external or internal diameter of a rigidly supported and rotating workpiece. Although the term cylindrical grinding may also be applied to centerless grinding, it generally refers to a workpiece that is ground in a chuck or between the supporting centers. Cylindrical grinders can be used to grind all types of hard or soft workpieces to a high degree of accuracy and very fine surface finishes ${ }^{1}$.

Over the years, researchers focused on improving the performance of machining operations with the aim of minimizing the costs and improving the quality of manufactured products ${ }^{2}$. Hassui and Diniz ${ }^{3}$ studied the effects of grinding parameters on the surface roughness and vibration and investigated the relation between the vibration and the surface roughness during the grinding of the AISI 52100 steel. Kwak ${ }^{4}$ stated that the geometric errors occurring during the grinding process were due to the rigidity of the grinding system and thermal effects. $\mathrm{He}$ also indicated that an accurate determination of the grinding parameters is of great importance for the reduction of such errors. During the cylindrical grinding of $\mathrm{Al} / \mathrm{SiC}$-metal-matrix composites, Thiagarajan et al. ${ }^{5}$ studied the effects of the grinding parameters on the grinding force, the surface roughness and the heat that emerges during the grinding. Fan and Miller ${ }^{6}$ developed a force model for grinding with segmental wheels. Both experimental and analytical results showed the average

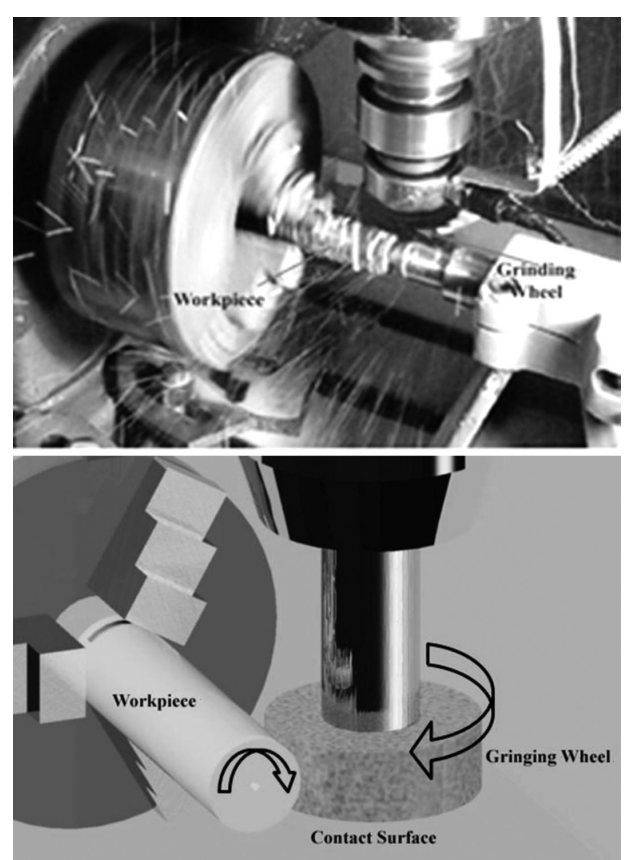

Figure 1: Position of the contact between the grinding wheel and workpiece

Slika 1: Položaj stika med brusnim kolesom in obdelovancem grinding force of the wheels in comparison with the conventional wheels. Larger spaces between the segments further reduce the average force and increase the surface roughness and peak force.

Hecker and Liang ${ }^{7}$ theoretically examined the relationship between the thickness of a chip that was undeformed in the cylindrical grinding process and the arithmetic surface roughness. They tried to verify this relation experimentally using the cylindrical grinding method. Gavas et al. ${ }^{8}$ machined four different materials using the helical scan-grinding (HSG) method. They investigated the effects of the cutting parameters on the surface roughness and roundness. They stated that the helical scan-grinding method decreased the surface roughness in comparison with the conventional cylindrical grinding method. Gołąbczak and Koziarski ${ }^{9}$ investigated the cutting capabilities of CBN grinding wheels in the grinding process. They studied the components of grinding forces, the surface roughness and the stresses on the surface layer.

A cylindrical grinder is a type of a grinding machine used to shape the outside of an object. The cylindrical grinder can work on a variety of shapes. However, the object must have the central axis of the rotation. This includes but is not limited to the shapes such as a cylinder, an ellipse, a cam or a crankshaft ${ }^{10}$. Agarwal and Venkateswara $\mathrm{Rao}^{11}$ investigated the relation between the chip thickness and the surface roughness in the grinding of ceramic materials. Nguyen and Zhang ${ }^{12}$ investigated the performance of a new, segmented, grinding-wheel system using the surface integrity of ground components as a criterion. The experimental results showed that the segmented grinding wheel had some obvious advantages in comparison with the standard wheel.

Rodrigo et al. ${ }^{13}$ studied the effects of tangential cutting forces on the surface roughness in the grinding process using cutting fluids flowing at different flow rates. Koshy et al. ${ }^{14}$ used the centerless-grinding-processing method by positioning the workpiece tangentially to the grinding wheel. They stated that this method creates a better surface finish than the conventional methods.

Upon the literature review, it is observed that the studies are mostly focused on the effects of the cutting parameters on the surface quality. It is determined that there is a limited number of the studies conducted on the selection of cutting tools or the location and movements of cutting tools and workpieces with respect to each other. A new approach to the cylindrical grinding method is introduced in this study. Within this new method, called the tangential cylindrical grinding, the outer surface of a cylindrical workpiece is in a tangential contact with the cutting tool and the axes of the cutting tool and the workpiece are made to be tangent to each other (Figure 1). This method allows us to use small grinding wheels instead of the grinding wheels with large diameters used with the conventional grinding. Moreover, the 
negative effects that may occur during the grinding with the wheels with large diameters are eliminated.

\subsection{Taguchi method and ANOVA}

The Taguchi experimental-design method minimizes the number of experiments, enabling experimental studies to be conducted in a shorter and easier way. This method was first introduced by Genichi Taguchi, a Japanese engineer. This method reduces the number of experiments that would otherwise last for a long time and have high costs ${ }^{15}$.

Analysis of variance is the predominant statistical method used to interpret experimental data and make the necessary decisions on whether this method is the most objective one. The column effect is used by Taguchi as a simplified ANOVA to subjectively identify the columns that have large influences on the response ${ }^{15}$. The aim of the analysis of variance is to evaluate the significance of the cutting parameters on the surface roughness for this paper. It gives a clear picture of how much the cutting parameters affect the response and the level of significance of the factor considered. Statistically, there is a tool called an $\mathrm{F}$ test allowing us to see which design parameter has a significant effect on the quality characteristic. Usually, when $\mathrm{F}>4$, it means that the change in the design parameter has a significant effect on the quality characteristic ${ }^{16}$.

Chang and $\mathrm{KuO}^{17}$ machined aluminium-oxide ceramics with laser machining using the Taguchi experimental-design method. They investigated the effects of the cutting parameters on the surface roughness and machining ratio in the experimental studies they conducted. Prabhu and Vinayagam ${ }^{18}$ used SAE20W40 nanocarbonreinforced oil in the machining of the AISI D3 tool steel with the grinding method. They used the Taguchi experimental-design method in planning and evaluating their experimental studies. Kwak and $\mathrm{Kim}^{19}$ investigated the effects of machining parameters on the geometric errors that appear on the surface, during the surface grinding, using the Taguchi and surface-response methods. They also developed a secondary surface-response model for a prior detection of any geometric error. Nalbant et al. ${ }^{20}$ used the Taguchi method to find the optimum cutting parameters for the surface roughness in turning. They provided experimental results to illustrate the effectiveness of this approach.

Gür ${ }^{21}$ alloyed the surface of medium-carbon steel using the PTA method and he investigated the wear resistance of this alloyed coating layer via the Taguchi method. He used the Taguchi design according to the $\mathrm{L}_{18}$ orthogonal array and experimentally evaluated the factors affecting the wear of the coating layer. The preparation of experimental study plans and an easy interpretation of the conducted experimental studies are the primary advantages of the Taguchi experimentaldesign method. An experimental study plan is formed following the determination of the relevant parameters to be used and their related levels and the selection of the orthogonal arrays appropriate for their levels of freedom. It is then converted into the performance characteristic called the $S / N$ (signal/noise) ratio for the interpretation of such experimental studies. The most commonly used performance characteristics are the smallest the best, the biggest the best and the nominal the best characteristics. The largest $S / N$ ratio represents the value of a parameter for the optimum level ${ }^{15}$.

\section{EXPERIMENTAL WORK}

\subsection{Experimental set-up and measurements}

A VMC-850 Johnford vertical, processing, centered workbench was used for designing the experimental set-up of the tangential cylindrical grinding as a new method. The flowchart for the optimization of the cutting parameters in the tangential cylindrical grinding process is shown in Figure 2.

The set-up mechanism shown in Figure 3 was installed for the workpiece to rotate around its own axis at desired rotation rates in the experimental set-up. A Micromaster 400 inverter was used for rotational adjustments. Furthermore, a grinding wheel used as the cutting tool could be easily installed on or demounted from a milling machine, acting as a milling tool. For the workpiece's rotation with no backlash, the workpiece was supported with the center on the other side.

Rotational adjustments were calibrated with an Extech Instruments 461880 tachometer and a vibration-

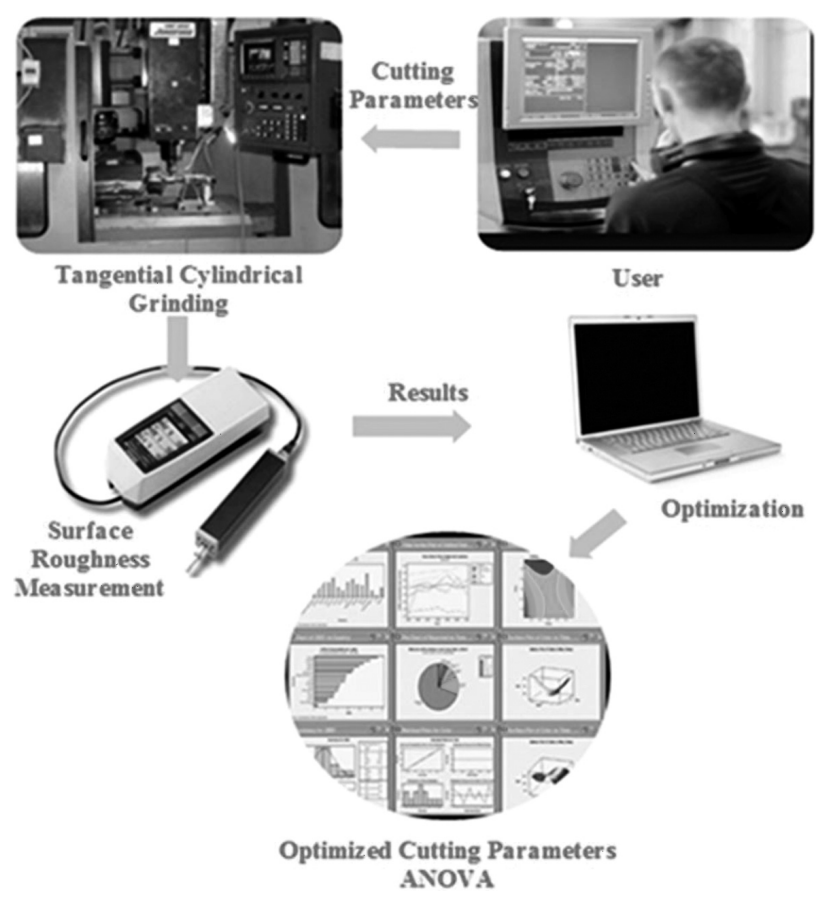

Figure 2: Flowchart for optimizing the cutting parameters in tangential cylindrical grinding process

Slika 2: Potek optimizacije parametrov rezanja pri postopku tangencialnega cilindričnega brušenja 


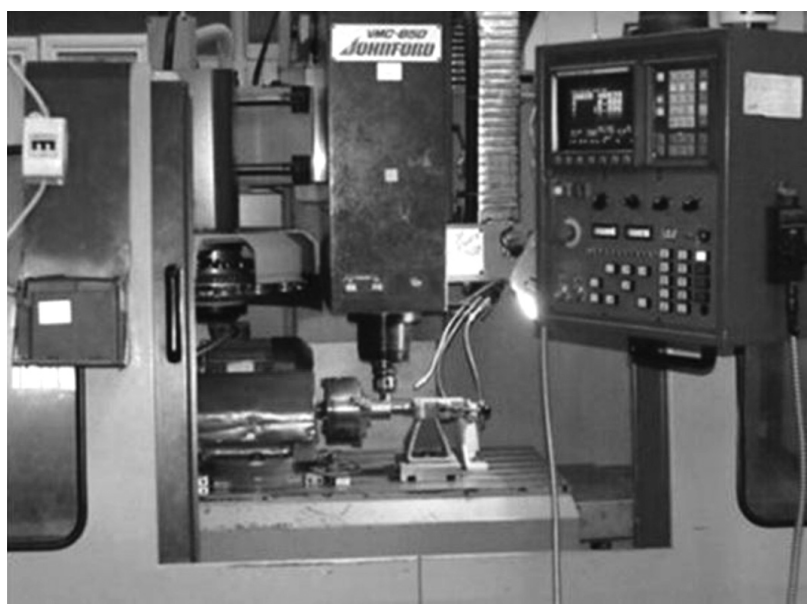

Figure 3: Tangential cylindrical grinding set-up mechanism

Slika 3: Postavitev mehanizma tangencialnega cilindričnega brušenja

measuring device. The parallelism adjustment of the workpiece was checked by means of a comparator.

$\varnothing 20 \times 60 \mathrm{~mm}$ AISI D3 tool steel was cut using a saw to conduct tangential cylindrical grinding experiments. The length of the workpiece was determined as per $L=$ $2 D$ ratio, where $L$ is the length and $D$ is the diameter of the workpiece. A center hole was opened on one side in order to enable the workpiece to be supported by the center. The machining was conducted by making the grinding wheel turn around its own axis, while being positioned tangentially to the workpiece's axis and with the feed motion providing the depth of cut.

The AISI D3 tool steel is used for manufacturing mold plates, powder-metallurgy tools, cold extrusion, punch dies, ceramic forming dies and cold punches. A 45s SIOUX 2145GP grinding wheel with a grain size of $100 \mu \mathrm{m}$ and a diameter of $R=44 \mathrm{~mm}$ was used to conduct the tangential cylindrical grinding experiments.

The average surface-roughness values of the parts machined with the tangential cylindrical grinding method were measured using Mitutoyo Surftest S-J210. The surface-roughness measurements were taken along the cylindrical workpiece's axis and in the direction of the feed rate. The measurements were taken from four different points of the machined surfaces and the average of the measurements was calculated.

\subsection{Experimental study}

$\mathrm{L}_{18}$ orthogonal arrays were used in the machining of the AISI D3 tool steel with the tangential cylindrical grinding method in this experimental study. The number of experiments and usage levels of the parameters were specified on the Taguchi toolbar of the Minitab 15 software program. Because of conducting these experiments, the surface-roughness values obtained from the surface of the relevant workpiece were converted into the $S / N$ ratio in the Minitab 15 software program. The following criteria were taken into consideration when determining the levels of the parameters used in the experimental studies:
- The levels of the depth of cut are generally determined as the depth of cut left for the grinding process and the values above this value.

- Relevant values were obtained from the tables according to the number of rotations of the grinding wheel, the number of rotations of the workpiece, the material features of the materials to be machined and the cutting tools to be used and the features of the workbench.

- The smallest feed rate of the workbench that was used for determining the parameters of the axial feed speed and higher feed rates were taken into consideration. Table 1 illustrates the parameters and the related levels to be used in the experiments.

Table 1: Machining parameters

Tabela 1: Parametri obdelave

\begin{tabular}{|c|c|c|c|c|c|}
\hline \multirow{2}{*}{ Cutting parameters } & \multirow{2}{*}{ Unit } & \multirow{2}{*}{ Symbol } & \multicolumn{3}{|c|}{ Levels } \\
\cline { 4 - 6 } & & & Level 1 & Level 2 & Level 3 \\
\hline Depth of cut & $\mathrm{mm}$ & $\mathrm{A}$ & 0.005 & 0.01 & - \\
\hline Wheel speed & $\mathrm{min}^{-1}$ & $\mathrm{~B}$ & 1000 & 1500 & 2000 \\
\hline Workpiece speed & $\mathrm{min}^{-1}$ & $\mathrm{C}$ & 220 & 320 & 420 \\
\hline Table feed rate & $\mathrm{mm} / \mathrm{min}$ & $\mathrm{D}$ & 3.2 & 7.9 & 12.6 \\
\hline
\end{tabular}

Considering the freedom degrees of these parameters, it was determined that the use of the $\mathrm{L}_{18}$ orthogonal array was appropriate. Table 2 illustrates the $\mathrm{L}_{18}$ orthogonal array used in the experimental studies.

Table 2: $\mathrm{L}_{18}$ orthogonal array for the experiments

Tabela 2: $\mathrm{L}_{18}$ ortogonalna namestitev preizkusov

\begin{tabular}{|c|c|c|c|c|}
\hline \multirow{2}{*}{$\begin{array}{l}\text { Trial } \\
\text { No }\end{array}$} & \multicolumn{4}{|c|}{ Levels of parameters } \\
\hline & $\begin{array}{l}\text { Depth of } \\
\text { cut }(\mathrm{mm})\end{array}$ & $\begin{array}{c}\text { Wheel speed } \\
\left(\mathrm{min}^{-1}\right)\end{array}$ & $\begin{array}{c}\text { Workpiece } \\
\text { speed }\left(\mathrm{min}^{-1}\right)\end{array}$ & $\begin{array}{l}\text { Table feed rate } \\
(\mathrm{mm} / \mathrm{min})\end{array}$ \\
\hline 1 & 0.005 & 1000 & 220 & 3.2 \\
\hline 2 & 0.005 & 1000 & 320 & 7.9 \\
\hline 3 & 0.005 & 1000 & 420 & 12.6 \\
\hline 4 & 0.005 & 1500 & 220 & 3.2 \\
\hline 5 & 0.005 & 1500 & 320 & 7.9 \\
\hline 6 & 0.005 & 1500 & 420 & 12.6 \\
\hline 7 & 0.005 & 2000 & 220 & 7.9 \\
\hline 8 & 0.005 & 2000 & 320 & 12.6 \\
\hline 9 & 0.005 & 2000 & 420 & 3.2 \\
\hline 10 & 0.01 & 1000 & 220 & 12.6 \\
\hline 11 & 0.01 & 1000 & 320 & 3.2 \\
\hline 12 & 0.01 & 1000 & 420 & 7.9 \\
\hline 13 & 0.01 & 1500 & 220 & 7.9 \\
\hline 14 & 0.01 & 1500 & 320 & 12.6 \\
\hline 15 & 0.01 & 1500 & 420 & 3.2 \\
\hline 16 & 0.01 & 2000 & 220 & 12.6 \\
\hline 17 & 0.01 & 2000 & 320 & 3.2 \\
\hline 18 & 0.01 & 2000 & 420 & 7.9 \\
\hline
\end{tabular}

\section{RESULTS}

Table 3 illustrates the results obtained from the processing of the AISI D3 tool steel, performed with the Taguchi test-design method, and the corresponding $S / N$ 
ratio values. The average surface roughness and the cutting parameters are present in Figures 4 to 6.

Examining Table 3 and Figures $\mathbf{4}$ and 6, it is observed that the surface roughness increases with the increase in the workpiece speed. During the grinding process, the workpiece speed is selected according to the grinding wheel and the characteristics of the workpiece material. Besides, there must be a proper ratio between the workpiece and the grinding-wheel speeds. In this study, it is found that as the workpiece speed increases, this ratio diverges from its proper value, the dynamic hardness of the grinding wheel decreases and the surface quality is reduced due to irregular abrasion. Examining Table $\mathbf{3}$ and Figures $\mathbf{4}$ and $\mathbf{5}$, it is observed that the surface roughness decreases while the grinding-wheel speed increases. Since the amount of the chips that each cutting wheel removes decreases with the increase in the grinding-wheel speed, it can be asserted that the machining force per wheel decreases and the vibration is

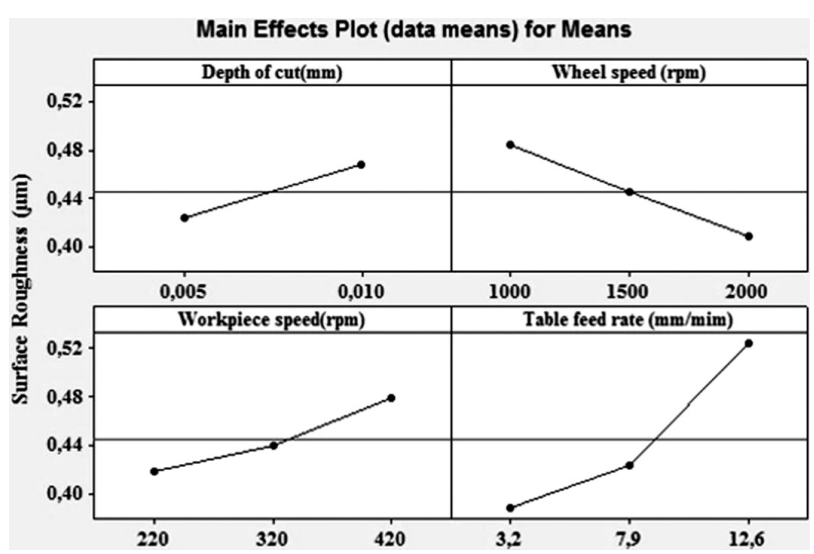

Figure 4: Effect of processing parameters on the average surface roughness of AISI D3 tool steel

Slika 4: Vpliv procesnih parametrov na povprečno hrapavost površine orodnega jekla AISI D3

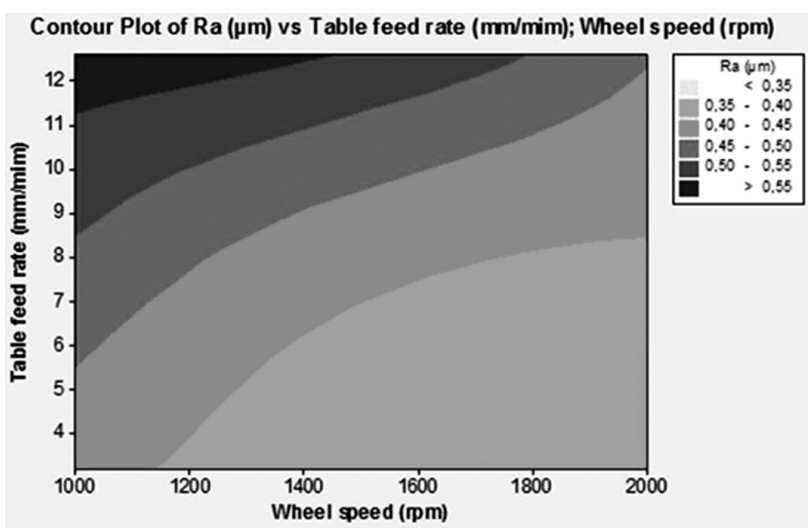

Figure 5: Effect of parameters "grinding-wheel speed" and "table feed rate" on the average surface roughness in machining of AISI D3 tool steel

Slika 5: Vpliv parametrov "hitrost brusilnega kolesa" in "hitrost podajanja mize" na povprečno hrapavost in obdelavnost orodnega jekla AISI D3 reduced correspondingly. In consequence, it is obvious from the results that the surface quality is good.

Table 3: Experimental results obtained from the studies of the average surface roughness and $S / N$ ratio

Tabela 3: Rezultati, dobljeni iz študija povprečne hrapavosti površine in razmerja $S / N$

\begin{tabular}{|c|c|c|c|c|c|c|}
\hline \multirow[b]{2}{*}{$\begin{array}{c}\text { Trial } \\
\text { No }\end{array}$} & \multicolumn{4}{|c|}{ Levels of parameters } & \multirow[b]{2}{*}{$\begin{array}{c}\text { Surface } \\
\text { roughness } \\
\left(R_{\mathrm{a}}\right) \\
(\mu \mathrm{m})\end{array}$} & \multirow[b]{2}{*}{$\begin{array}{c}S / N \\
\text { ratio }\end{array}$} \\
\hline & $\begin{array}{l}\text { Depth } \\
\text { of cut } \\
(\mathrm{mm})\end{array}$ & $\begin{array}{l}\text { Wheel } \\
\text { speed } \\
\left(\mathrm{min}^{-1}\right)\end{array}$ & $\begin{array}{l}\text { Work- } \\
\text { piece } \\
\text { speed } \\
\left(\mathrm{min}^{-1}\right)\end{array}$ & $\begin{array}{c}\text { Table feed } \\
\text { rate } \\
(\mathrm{mm} / \mathrm{min})\end{array}$ & & \\
\hline 1 & 0.005 & 1000 & 220 & 3.2 & 0.37 & 8.635 \\
\hline 2 & 0.005 & 1000 & 320 & 7.9 & 0.46 & 6.744 \\
\hline 3 & 0.005 & 1000 & 420 & 12.6 & 0.59 & 4.582 \\
\hline 4 & 0.005 & 1500 & 220 & 3.2 & 0.34 & 9.370 \\
\hline 5 & 0.005 & 1500 & 320 & 7.9 & 0.42 & 7.535 \\
\hline 6 & 0.005 & 1500 & 420 & 12.6 & 0.55 & 5.192 \\
\hline 7 & 0.005 & 2000 & 220 & 7.9 & 0.35 & 9.118 \\
\hline 8 & 0.005 & 2000 & 320 & 12.6 & 0.43 & 7.330 \\
\hline 9 & 0.005 & 2000 & 420 & 3.2 & 0.36 & 8.873 \\
\hline 10 & 0.01 & 1000 & 220 & 12.6 & 0.56 & 5.036 \\
\hline 11 & 0.01 & 1000 & 320 & 3.2 & 0.46 & 6.744 \\
\hline 12 & 0.01 & 1000 & 420 & 7.9 & 0.52 & 5.679 \\
\hline 13 & 0.01 & 1500 & 220 & 7.9 & 0.41 & 7.744 \\
\hline 14 & 0.01 & 1500 & 320 & 12.6 & 0.54 & 5.352 \\
\hline 15 & 0.01 & 1500 & 420 & 3.2 & 0.41 & 7.744 \\
\hline 16 & 0.01 & 2000 & 220 & 12.6 & 0.48 & 6.375 \\
\hline 17 & 0.01 & 2000 & 320 & 3.2 & 0.39 & 8.178 \\
\hline 18 & 0.01 & 2000 & 420 & 7.9 & 0.44 & 7.130 \\
\hline
\end{tabular}

When Table 3 and Figures 4 to $\mathbf{6}$ are examined, it is seen that the surface roughness increases with the increase in the depth of cut and the feed rate.

The surface roughness generally increases as the feed rate increases. It can be concluded that with the increase in the depth of cut and feed rate, the cutting forces and, accordingly, the vibration increase during the processing of the AISI D3 tool steel with the tangential cylindrical grinding method. In addition, with the increasing vibration, the surface roughness increases during the machining process. In a study conducted by Demir it is stated

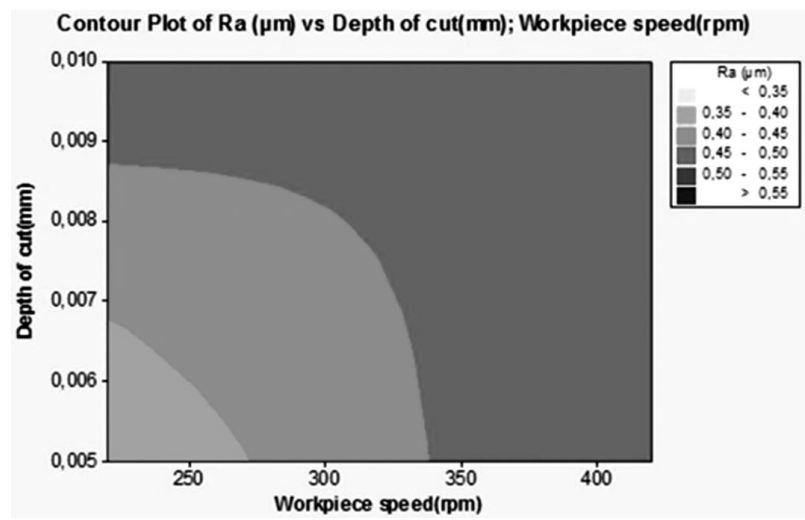

Figure 6: Effect of parameters "workpiece speed" and "depth of cut" on the average surface roughness in machining of AISI D3 tool steel Slika 6: Vpliv parametrov "hitrost obdelovanca" in "globina reza" na povprečno hrapavost površine pri obdelavi orodnega jekla AISI D3 
that the cutting section and the grinding force increase because of the increase in the depth of cut, and thus, the abrasion rate of the wheel and the average surface roughness increase en, $23^{23}$.

Table 4 illustrates the $S / N$ ratios, which correspond with the surface-roughness rates obtained according to the parameter levels during the processing of the AISI D3 tool-steel material. In this table, the optimum levels of the processing parameters are shown with $\left({ }^{a}\right)$.

Table 4: Effect of the factors at each level on the surface roughness in the machining of AISI D3 tool steel ( $S / N$ ratio)

Tabela 4: Vpliv faktorjev na vsakem nivoju na hrapavost površine pri obdelavi orodnega jekla AISI D3 ( $S / N$ razmerje)

\begin{tabular}{|c|c|c|c|c|}
\hline \multirow{2}{*}{ Cutting Parameters } & \multirow{2}{*}{ Symbol } & \multicolumn{3}{|c|}{ Average $S / N$ rate $(\mathrm{dB})$} \\
\cline { 3 - 5 } & & Level 1 & Level 2 & Level 3 \\
\hline Depth of cut & $\mathrm{A}$ & $7.49^{\mathrm{a}}$ & 6.67 & - \\
\hline Wheel speed & $\mathrm{B}$ & 6.24 & 7.16 & $7.83^{\mathrm{a}}$ \\
\hline Workpiece speed & $\mathrm{C}$ & $7.71^{\mathrm{a}}$ & 6.98 & 6.53 \\
\hline Table feed rate & $\mathrm{D}$ & $8.26^{\mathrm{a}}$ & 7.33 & 5.64 \\
\hline
\end{tabular}

When the results were examined, it was determined that the A1, B3, C1 and D1 levels indicated the optimum parameters in the evaluation of the effects of the cutting parameters on the average surface roughness.

In conclusion, it is evidently seen in the experimental studies conducted that the cutting parameters lead to results that are similar to those for the external surface obtained in the cylindrical grinding process with the tangential cylindrical grinding method. The study allows the grinding wheels with a smaller diameter to be used in conventional cylindrical grinding instead of the grinding wheels with a large diameter. In addition, the problems that may occur when fixing and using the grinding wheels with a large diameter are minimized. Moreover, it is possible to perform the grinding process on a turning/ milling machine.

In this paper, the aim of the analysis of variance is to evaluate the effects of the cutting parameters on the average surface roughness. The analysis clearly shows how much the cutting parameters affect the response and the level of significance of the factor considered. Table 5 shows the results of ANOVA for the average surface roughness. It can be seen from this table that the table feed rate and the wheel speed are the most significant cutting parameters affecting the surface roughness. Therefore, based on the $S / N$ and ANOVA analyses, the optimum cutting parameters are the depth of cut at level 1 , the wheel speed at level 3, the workpiece speed at level 1 and the feed rate at level 1 . However, the most significant cutting parameter contributing the most to the quality characteristic, i.e., the average surface roughness is the table feed rate $(56.27 \%)$. The error rate of $4.56 \%$ was found with the ANOVA.
Table 5: ANOVA analysis of the average surface roughness obtained during the processing of AISI D3 tool steel

Tabela 5: Analiza ANOVA povprečne hrapavosti površine, dobljene pri obdelavi orodnega jekla AISI D3

\begin{tabular}{|c|c|c|c|c|c|}
\hline $\begin{array}{l}\text { Cutting } \\
\text { parameters }\end{array}$ & $\begin{array}{c}\text { Degree } \\
\text { of } \\
\text { freedom }\end{array}$ & $\begin{array}{l}\text { Sum of } \\
\text { square }\end{array}$ & Variance & $F$ ratio & $\begin{array}{c}\text { Contri- } \\
\text { bution } \\
(\%)\end{array}$ \\
\hline $\begin{array}{l}\text { Depth of cut } \\
(\mathrm{mm})\end{array}$ & 1 & 3.041 & 3.041 & 30.586 & 7.940 \\
\hline $\begin{array}{l}\text { Wheel speed } \\
\left(\min ^{-1}\right)\end{array}$ & 2 & 7.711 & 3.855 & 38.780 & 20.279 \\
\hline $\begin{array}{c}\text { Workpiece } \\
\text { speed }\left(\min ^{-1}\right)\end{array}$ & 2 & 4.253 & 2.126 & 21.393 & 10.946 \\
\hline $\begin{array}{l}\text { Table feed rate } \\
(\mathrm{mm} / \mathrm{min})\end{array}$ & 2 & 21.044 & 10.522 & 105.830 & 56.270 \\
\hline Error & 10 & 0.994 & 0.099 & - & 4.562 \\
\hline Total & & 37.044 & - & - & - \\
\hline
\end{tabular}

\section{CONCLUSIONS}

In this study, the AISI D3 tool steel was machined with tangential cylindrical grinding introduced as a new method. Using the variance analysis (ANOVA), the effects of different parameter levels on the average surface roughness were analyzed. The experimental studies were evaluated using the Taguchi experimental design method and ANOVA; the following results were obtained:

- It was determined that the average surface roughness increases with the increase in the workpiece speed during the processing of the AISI D3 tool-steel material with the tangential grinding method. It was observed that the best value of the average surface roughness was obtained at the first level.

- It was observed that the average surface-roughness rate increases with the increase in the depth of cut and the axial-feed rate during the processing of the AISI D3 tool-steel material. The most appropriate levels were the first levels.

- It was observed that the average surface roughness decreases with the increase in the grinding-wheel speed during the processing of the AISI D3 tool-steel material.

- The ANOVA results for all the cutting parameters affecting the average surface roughness showed that the configuration analysis has a certain effect.

- Using the Taguchi method and the $S / N$ rate, parameter levels A1, B3, C1, D1 were used to obtain the optimum average surface roughness.

- The tangential cylindrical grinding process as a new method enabled us to use the grinding wheels with smaller diameters compared to the diameter of the grinding wheels used in conventional cylindrical grinding and the obtained surface quality was similar to the quality of fine grinding. 


\section{Acknowledgement}

The authors would like to acknowledge the Firat University, Turkey, for the financial support (Project No. FUBAP-TEF.11.06).

\section{REFERENCES}

${ }^{1}$ H. A. Youssef, H. El-Hoppy, Machining Technology, Machine Tools and Operations, CRC Press, 2008

${ }^{2}$ N. H. Rafai, M. N. Islam, An investigation into dimensional accuracy and surface finish achievable in dry turning, Machining Science and Technology, 13 (2009) 4, 571-589, doi:10.1080/ 10910340903451456

${ }^{3}$ A. Hassui, A. E. Diniz, Correlating surface roughness and vibration on plunge cylindrical grinding of steel, International Journal of Machine Tools \& Manufacture, 43 (2003), 855-862, doi:10.1016/ S0890-6955(03)00049-X

${ }^{4}$ J. S. Kwak, Application of Taguchi and response surface methodologies for geometric error in surface grinding process, International Journal of Machine Tools and Manufacture, 45 (2005) 3, 327-334, doi:10.1016/j.ijmachtools.2004.08.007

${ }^{5}$ C. Thiagarajan, R. Sivaramakrishnan, S. Somasundaram, Experimental evaluation of grinding forces and surface finish in cylindrical grinding of $\mathrm{Al} / \mathrm{SiC}$ metal matrix composites, Proceedings of the Institution of Mechanical Engineers, Part B: Journal of Engineering Manufacture, 225 (2011) 9, 1606-1614, doi:10.1177/ 0954405411398761

${ }^{6}$ X. Fan, M. H. Miller, Force analysis for grinding with segmental wheels, Machining Science and Technology: An International Journal, 10 (2006) 4, 435-455, doi:10.1080/10910340600996142

${ }^{7}$ R. L. Hecker, S. Y. Liang, Predictive modelling of surface roughness in grinding, International Journal of Machine Tools and Manufacture, 43 (2003) 8, 755-761, doi:10.1016/S0890-6955(03)00055-5

${ }^{8}$ M. Gavas, İ. Karacan, E. Kaya, A novel method to improve surface quality in cylindrical grinding, Experimental Techniques, 35 (2011) 1, 26-32, doi:10.1111/j.1747-1567.2009.00575.x

${ }^{9}$ A. Gołąbczak, T. Koziarski, Assessment method of cutting ability of CBN grinding wheels, International Journal of Machine Tools and Manufacture, 4 (2005) 11, 1256-1260, doi:10.1016/j.ijmachtools. 2005.01.008

${ }^{10}$ C. N. de Souza, R. E. Catai, P. R. de Aguiar, M. H. Salgado, E. C. Bianchi, Analysis of diametrical wear of grinding wheel and roundness errors in the machining of steel, J. of the Braz. Soc. of Mech. Sci. \& Eng. by ABCM, XXVI (2004) 2, 209, doi:10.1590/S167858782004000200013

${ }^{11} \mathrm{~S}$. Agarwal, P. Venkateswara Rao, A probabilistic approach to predict surface roughness in ceramic grinding, International Journal of Machine Tools and Manufacture, 45 (2005) 6, 609-616, doi:10.1016/ j.ijmachtools.2004.10.005
${ }^{12}$ T. Nguyen, L. C. Zhang, Performance of a new segmented grinding wheel system, International Journal of Machine Tools and Manufacture, 49 (2009) 3-4, 291-296, doi:10.1016/j.ijmachtools.2008.10.015

${ }^{13}$ D. M. Rodrigo, C. B. Eduardo, E. C. Rodrigo, R. A. Paulo, Analysis of the different forms of application and types of cutting fluid used in plunge cylindrical grinding using conventional and super abrasive CBN grinding wheels, International Journal of Machine Tools and Manufacture, 46 (2006) 2, 122-131, doi:10.1016/j.ijmachtools.2005. 05.009

${ }^{14}$ P. Koshy, Y. Zhou, C. Guo, R. Chand, Novel kinematics for cylindrical grinding of brittle materials, Annals of CIRP, 54 (2005), 289-292, doi:10.1016/S0007-8506(07)60105-X

${ }^{15}$ P. J. Ross, Taguchi Techniques for Quality Engineering, McGrawHill, 1995

${ }^{16}$ W. H. Wang, Y. S. Tarng, Design optimization of cutting parameters for turning operations based on the Taguchi method, Journal of Materials Processing Technology, 84 (1998), 122-129, doi:10.1016/ S0924-0136(98)00079-X

${ }^{17}$ C. W. Chang, C. P. Kuo, Evaluation of surface roughness in laser-assisted machining of aluminum oxide ceramics with Taguchi method, International Journal of Machine Tools and Manufacture, 47 (2007), 141-147, doi:10.1016/j.mach tools.2006.02.009

${ }^{18} \mathrm{~S}$. Prabhu, B. K. Vinayagam, AFM investigation in grinding process with nano fluids using Taguchi analysis, Int. J. Adv. Manuf. Technol., 60 (2012), 149-160, doi:10.1007/s00170-011-3599-5

${ }^{19}$ J. S. Kwak, I. K. Kim, Parameter optimization of surface grinding process based on Taguchi and response surface methods, Key Engineering Materials, 306-308 (2006), 709-714, doi:10.4028/www. scientific.net/KEM.306-308.709

${ }^{20}$ M. Nalbant, H. Gokkaya, G. Sur, Application of Taguchi method in the optimization of cutting parameters for surface roughness in turning, Materials and Design, 28 (2007) 4, 1379-1385, doi:10.1016/ j.matdes.2006.01.008

${ }^{21} \mathrm{~A}$. K. Gür, Investigating the wear behaviour of $\mathrm{FeCrC} / \mathrm{B}_{4} \mathrm{C}$ powder alloys coating produced by plasma transferred arc weld surfacing using the Taguchi method, MP Materials Testing, 55 (2013) 6, 462-467, doi:10.3139/120.110463

${ }^{22}$ H. Demir, A. Güllü, Investigation the effects of processing parameters and wheel hardness on the surface roughness and grinding forces, Gazi University Journal of the Faculty of Engineering and Architecture, 3 (2008), 577-584, http://www.mmfdergi.gazi.edu.tr/ article/view/1061000403

${ }^{23}$ C. Ozay, H. Ballikaya, V. Savas, Investigation on surface roughness of D3 tool steel using tangential cylindrical grinding method, Proc. of the EuroTecS 2013, European Conference of Technology and Society, Sarajevo, Bosnia and Herzegovina, 2013, 377-384 